\section{Dental and oral nonmetric traits in a Coimbra reference sample: testing intrasample chronological and spatial variation}

\author{
Luís Miguel Marado ${ }^{1},{ }^{2}$, Ana Maria Silva ${ }^{3},{ }^{4,}$ \\ 1 Unidade de Arqueologia da Universidade do Minho, Edifício dos \\ Congregados, Avenida Central 100, 4710-229 Braga, Portugal \\ 2 Lab2PT - Landscape, Heritage and Territory Laboratory, University \\ of Minho, Avenida Central 100, 4710-229 Braga, Portugal \\ 3 Prehistory Laboratory, CIAS, University of Coimbra, \\ Coimbra, Portugal \\ 4 UNIARQ - WAPS, University of Lisbon Archaeology Center, \\ Lisbon, Portugal \\ 5 Laboratory of Forensic Anthropology, Center for Functional \\ Ecology, University of Coimbra, Coimbra, Portugal
}

Corresponding author: luismarado@gmail.com

\begin{abstract}
A reference sample of dental and oral nonmetric traits should represent its biological population from which it stems. The presence of individuals born at different times, different regions, and separate countries in the Coimbraidentified cranial collections provides the test of whether this sample reflects the biological continuity of this Portuguese sample among the late modern (early industrialization, nineteenth century) to early contemporary (early demographic transition, first half of the twentieth century) population of this region of central Portugal. The Coimbra collections were scored for 61 traits using methodology by Hauser and De Stefano (1989), Turner et al. (1991), Scott and Turner (1997), Irish (1998), and Marado and Silva (2016). The 600
\end{abstract}

individuals in the sample were divided by generation, region, and nationality. Their phenetic diversity was tested with principal component analysis and with the mean measure of divergence statistic. The proximity between the subsamples was generalized, and it mimicked previous genetic marker results. Some small subsamples hindered conclusions; nevertheless, this Coimbra sample is considered a reliable dental reference sample for the Portuguese late modern/early contemporary population.

Keywords Dental anthropology $\cdot$ Regional heterogeneity . Generational heterogeneity $\cdot$ MMD $\cdot$ PCA

\section{Introduction}

The three Coimbra-identified osteological collections are among the most completely documented skeletal assemblages, since the samples are well preserved and each individual has full records, such as cause of death, sex, age, date of death, and place of birth (Cunha and Wasterlain 2007). These collections were gathered between 1895 and 1942. Samples from these collections have been used in scientific research since 1897 (Rocha 1995), and the members of those collections are usually claimed to be a representative of the Portuguese or central Portuguese population.

Because of the known provenience of its members, the Coimbra late modern (period corresponding to early industrialization, corresponding to the nineteenth century in Portugal) to early contemporary (period of early demographic transition from high to lower birth and death rates, during the first half of the twentieth century in Portugal)-identified cranial collections are considered appropriate for establishment of a Portuguese nonmetric dental reference sample. This reference sample is meant to be used in the estimation of biological relations with other samples as well as to assist in answering some of the many archaeological, historical, and anthropological questions concerning population movement and cultural contact in the Portuguese territory since prehistory. 
Encompassing members of several generations (individuals born between 1820 and 1924), the large sample is assumed to be a biological representative of the Portuguese population between the nineteenth and mid-twentieth centuries. However, the sample also includes individuals born in other European countries, individuals born in Brazil and in Africa, as well as individuals whose birthplace is unknown. Nevertheless, this collection of individuals has been considered a representative of the Portuguese population because they died in Coimbra. As such, they were regarded as a part of the gene pool of Portuguese inhabitants and were relatively randomly selected as a part of the Coimbra-identified anthropological collections.

The majority of the Coimbra samples hails from the eponymous district. Nevertheless, a full third of the sample was born in some 15 other districts. Sobral (2004) reviewed the political and social views on the biological heterogeneity or unity of Portugal from the late nineteenth/early twentieth centuries. Most authors, according to their regionalist views, commented on how the influence of either the Semitics (Arab, Berber, and Jewish presences in Iberia from the eighth to the fifteenth century, most prominent in the south) or the Celts (proto-historic BArian^ ${ }^{\wedge}$ people claimed to have occupied northern Iberia in the Iron Age) found in the southern and northern portions of Portugal, respectively, contaminated the valuable inheritance from Indo-European, Roman, and Greek origins. The Lusitanians, a proto-historic group who are considered the indigenous people of Portugal, were also cited as a positive biological influence (Sobral 2004; e.g., Mendes Corrêa 1919). From the mid-twentieth century onwards, the Lusitanians were seen as the main source of the Portuguese national identity as a single people with no biologically distinguishable subgroups; this notion was only questioned by popular opinion in the north (Sobral 2004).

However, unworthy of scientific merit, preconceptions regarding Portugal's internal biological diversity were based on past population movements into Portuguese territory. The (possible) first major migration into Portugal corresponds to the Mesolithic-Neolithic transition, a debated issue (e.g., Zilhão 1993; Jackes et al. 1997, 2001; Brandt et al. 2014). The Celtic incursion into Iberia, a not less polemic possible migration (e.g., Gamito 2005; Lorrio and Ruiz Zapatero 2005; Igrejas 2007), occurred during proto-history. Rome expanded into Iberia before its imperial phase (late third century bce), an occupation that lasted centuries and saw the arrival of urban elites and colonizing armies with unknown biological impact (Tsirkin 1989). Germanic peoples, namely Suebi (Díaz 2000) and Visigoths (Collins 2004), occupied northern and central portions of Portugal during and after the fall of the Roman Empire, since 409 ce. Finally, in the period between the early eighth and mid-fifteenth centuries, Iberia was occupied by Islamic (mainly North African Berber) presence throughout its territory, with few exceptions; however, their presence was much longer in the south of Iberia (Silverstein 2010). Therefore, biological heterogeneity should also be accounted for and measured when establishing anthropological reference samples. This intrasample variation can also be informative of the biological implications of past migrations.

Genetic studies suggest some biological continuity in Iberia from the Holocene onwards (McEvoy et al. 2004; Sampietro et al. 2005; Brandt et al. 2014), with increased variation coming from the Roman and Islamic presences, at least (Adams et al. 2008; Santos et al. 2014; Regueiro et al. 2015), and occasional evidence of biological heterogeneity within the peninsula, but rarely among Portuguese regions (Pereira et al. 2000, 2006; Beleza et al. 2006; Mairal et al. 2013; Martiniano et al. 2013).

The objective of this study is to test whether the phenotypic variability present in these individuals who died in Coimbra is consistent with the likely genetic characteristics of late modern/early contemporary Portugal, or is affected, either by the long time frame, or by the presence of foreigners, or by the disproportionate regional representation of the Portuguese territory.

\section{Materials}

The sample is composed of the crania and mandibles of 600 individuals, encompassing 300 males and 300 females, who died in Coimbra, Portugal, from the late nineteenth to the early to mid-twentieth century. They are mostly from the Trocas Internacionais (international trades; 300 male and 269 female individuals) collection, with some additional material from the Escolas Médicas (medical schools; 31 females) collection. These cranial collections are kept at the Department of Life Sciences, Faculty of Sciences and Technology, University of Coimbra. The primary criterion for selection was the presence of at least five maxillary and five mandibular teeth. Dentitions with heavily worn or damaged dentitions (with fractures or caries, for example) were avoided, when possible. These criteria led to the difference in the proportions of each collection, since Escolas Médicas is older, on average. The final sample was selected after both collections were analyzed.

The individuals in the sample died between 7 and 97 years of age (mean age at death 35.84 years). They were born approximately between 1820 and 1924 (the years of birth were calculated by subtracting the recorded age of each individual to the recorded date of death) and died between 1896 and 1938. The places of birth were diverse: (1) most individuals (585) were born in continental Portugal, but (2) one was born in the Madeira Archipelago (Portuguese territory, originally populated by the Portuguese), (3) five were born in Spain, (4) two were born in Brazil, (5) one was born in France, (6) one was born in Africa, and (7) five was born in an unknown location (most likely in Portugal, since they were given up for adoption at an early age in that country). 


\section{Methods}

Twenty-four nonmetric dental traits and two oral bone exostoses were scored according to the Arizona State University Dental Anthropology System (ASUDAS; Turner et al. 1991). In actuality, a total of 52 tooth-trait combinations were scored using the ASUDAS, since many of these traits were scored in more than one tooth each. Correlations between all pairs of traits were tested (results not shown; see Marado and Silva 2016 for correlations between the mandibular molar pittubercle (MMPT) and protostylid), and only UP3 and UP4 odontomes were correlated. Since this is a very rare trait and pooled results for all premolars are commonly reported (e.g., Scott and Turner 1997; Irish 1998), this correlation was disregarded.

Some discrete traits were scored using different methods, because they were not included in ASUDAS: (1) midline diastema, as per Irish (1998); (2) upper premolar accessory crests and mesial marginal accessory tubercles, scored according to Scott and Turner (1997) ${ }^{1}$; (3) the MMPT, scored according to Marado and Silva (2016) (using methodology adapted from Weets 2004, 2009); and (4) Hauser and De Stefano's (1989) method, used to score the foramina mentales and mylohyoid bridges.

Both sides of each dental arcade were observed and scored. Following the individual count method, we used the greatest trait expression regardless of side. Finally, the expression count method (Turner 1985) was used to better discriminate the subsamples analyzed. This method allows for a better representation of smaller samples. It also permits the comparison of very similar samples. The frequency of each trait grade is given a weight relative to the grade's position in the total number of grades. This allows the discrimination of samples by trait expression distribution and the dilution of the random differences caused by smaller sample sizes (Turner 1985).

After reviewing data for Western countries (developed and less developed) and hunter-gatherer groups, Fenner (2005) suggests a generation interval of 28 years for human populations. The present sample was divided into generations according to Fenner's (2005) suggestion: G1 (1820-1847; 13 individuals), G2 (1848-1875; 96 individuals), G3 (18761903; 294 individuals), and G4 (1904-1924; 194 individuals). Three individuals were not included because their date of death was not recorded.

Individuals from Portugal were divided into three geographically based regions: (1) north (107 individuals from Aveiro, Braga, Guarda, Porto, Viana do Castelo, Vila Real, and Viseu districts), (2) center (466 individuals from Castelo Branco, Coimbra, Leiria, Lisboa, and Santarém districts), and (3) south (12 individuals from Évora, Faro, Portalegre, and

\footnotetext{
${ }^{1}$ The work of Burnett et al. (2010) on maxillary premolar accessory ridges, MxPAR, was not yet known by the present authors at the time of trait selection.
}

Setúbal districts). All of these individuals were pooled into a Portuguese sample, along with the individual born in the Madeira Archipelago and those of unknown birthplace. These Portuguese and nine foreign-born individuals constitute the full membership encompassed by the Coimbra reference sample considered here (C-Pt; 600 individuals).

Principal component analysis (PCA) is a quantitative approach used to reduce data. Percentages/frequencies of dichotomous dental morphology data can be used, as previous research exemplifies (see Irish and Guatelli-Steinberg 2003). PCA compounds and re-expresses variables as combinations along composite axes, components, or factors. These factors (which can be graphically plotted) are less numerous and more coherent and so are typically more easily interpreted. This quantitative method also analyzes the correlation between the original variables and the resulting factors. These correlations indicate which variables are most responsible for the distribution of the samples along each component (Irish and Guatelli-Steinberg 2003; Delgado-Burbano 2007a, b; Harris 2008).

The mean measure of divergence (MMD) is the most commonly used statistic in the calculation of the phenotypic distance between the samples in dental anthropology. This is due to its easy computation and utility with nominal data. Variables that are correlated should be removed, since it assumes variable independence. This statistic, MMD, calculates divergence. The closer to 0 , the more similar the samples. Conversely, the closer to 1 , the more different the samples (Tyrrell 2000; Edgar 2004; Harris and Sjøvold 2004).

PCA and MMD were both used because their different contributions are complementary. Namely, PCA provides information on each trait's contribution to the variation between the subsamples, yet MMD provides a distance statistic and a $p$ value, allowing for easier comparison and result evaluation.

PCA was calculated using IBM SPSS version 19.0. MMD was computed with R 3.1.0 (R Core Team 2013), with Sołtysiak's (2011) R script, using Freeman and Tukey's (1950) small sample correction and Harris and Sjøvold's (2004) uncorrected formula. The MMD was used in an effort to assess the quantitative differences and biological divergence between the generations, regions, and nationalities encompassed by the Coimbra-identified cranial collections.

\section{Results}

Biological affinities among generations

The 36 dental and oral nonmetric traits that presented variation were included in the comparison among generations (Table 1).

Table 2 provides the eigenvalues and percentage of variation accounted for by each of the first three principal components. 
Table 1 Trait expressions for the Coimbra-identified cranial collections' generations

\begin{tabular}{|c|c|c|c|c|c|}
\hline \multirow[t]{2}{*}{ Trait } & & \multicolumn{4}{|c|}{ Generations } \\
\hline & & G1 & G2 & G3 & G4 \\
\hline Distal accessory ridge UC & $\%$ & $\begin{array}{c}15.0 \\
8\end{array}$ & $\begin{array}{l}15.2 \\
66\end{array}$ & 224.4 & $\begin{array}{l}35.1 \\
167\end{array}$ \\
\hline \multirow[t]{2}{*}{ Distal accessory ridge LC } & $\%$ & 8.0 & 9.9 & 13.3 & 13.0 \\
\hline & $\mathrm{n}$ & $\begin{array}{l}10 \\
12.5\end{array}$ & $\begin{array}{l}79 \\
3.9\end{array}$ & $\begin{array}{c}241 \\
2.6\end{array}$ & $\begin{array}{c}179 \\
4.0\end{array}$ \\
\hline Winging UI1 & $\mathrm{n}$ & $\begin{array}{l}8 \\
0.0\end{array}$ & $\begin{array}{c}57 \\
1.9\end{array}$ & $\begin{array}{l}185 \\
2.1\end{array}$ & $\begin{array}{c}132 \\
3.9\end{array}$ \\
\hline Shoveling UI1 & $\mathrm{n}$ & 4 & 26 & 129 & 103 \\
\hline Midline diastema & $\begin{array}{l}\% \\
\mathrm{n}\end{array}$ & $\begin{array}{l}0.0 \\
3\end{array}$ & $\begin{array}{l}32.3 \\
31\end{array}$ & $\begin{array}{l}9.2 \\
109\end{array}$ & $\begin{array}{c}4.1 \\
73\end{array}$ \\
\hline \multirow{2}{*}{ Interruption groove UI2 } & $\%$ & 28.6 & 19.3 & 12.2 & 22.7 \\
\hline & $\begin{array}{l}\mathrm{n} \\
\%\end{array}$ & $\begin{array}{l}7 \\
0.0\end{array}$ & $\begin{array}{c}57 \\
0.0\end{array}$ & $\begin{array}{l}213 \\
2.8\end{array}$ & $\begin{array}{c}172 \\
10.2\end{array}$ \\
\hline Accessory ridge UP3 & $\stackrel{\mathrm{H}}{\%}$ & $\begin{array}{l}7 \\
0.0\end{array}$ & $\begin{array}{c}83 \\
0.0\end{array}$ & $\begin{array}{l}215 \\
2.3\end{array}$ & $\begin{array}{l}176 \\
5.6\end{array}$ \\
\hline Accessory ridge UP4 & $\%$ & 22.2 & 3.3 & 23.0 & 36.3 \\
\hline Earabdili's trait UM1 & $\begin{array}{l}\mathrm{n} \\
8 / 8 \\
\mathrm{~A}\end{array}$ & $\begin{array}{c}9 \\
9.9 \\
19 \\
19\end{array}$ & $\begin{array}{c}61 \\
9.7 \\
36\end{array}$ & $\begin{array}{c}217 \\
12.6 \\
2326\end{array}$ & $\begin{array}{c}179 \\
18 \\
183 \\
183\end{array}$ \\
\hline $\begin{array}{l}\text { Mesial marginal accessory } \\
\text { tubercle UM1 }\end{array}$ & $\begin{array}{l}\% \\
\mathrm{n}\end{array}$ & $\begin{array}{l}0.0 \\
10\end{array}$ & $\begin{array}{l}0.0 \\
57\end{array}$ & 208 & $\begin{array}{c}9.4 \\
181\end{array}$ \\
\hline Hypocone UM2 & $\begin{array}{l}\% \\
\mathrm{n}\end{array}$ & $\begin{array}{c}31.5 \\
9\end{array}$ & $\begin{array}{l}43.7 \\
66\end{array}$ & $\begin{array}{l}49.2 \\
264\end{array}$ & $\begin{array}{c}56.0 \\
188\end{array}$ \\
\hline Enamel extension UM3 & $\begin{array}{l}\% \\
\mathrm{n}\end{array}$ & $\begin{array}{l}0.0 \\
1\end{array}$ & $\begin{array}{l}2.5 \\
27\end{array}$ & 133 & $\begin{array}{c}8.5 \\
59\end{array}$ \\
\hline Lingual cusp variation LP3 & $\begin{array}{l}\% \\
\mathrm{n}\end{array}$ & $\begin{array}{l}6.7 \\
10\end{array}$ & $\begin{array}{l}9.5 \\
83\end{array}$ & $\begin{array}{l}10.7 \\
253\end{array}$ & $\begin{array}{l}10.5 \\
177\end{array}$ \\
\hline Lingual cusp variation LP4 & $\begin{array}{l}\% \\
\mathrm{n}\end{array}$ & $\begin{array}{c}25.9 \\
9\end{array}$ & $\begin{array}{l}21.6 \\
77\end{array}$ & $\begin{array}{l}19.1 \\
247\end{array}$ & $\begin{array}{l}23.2 \\
166\end{array}$ \\
\hline Deflecting wrinkle LM1 & $\begin{array}{l}\% \\
\mathrm{n}\end{array}$ & $\begin{array}{l}0.0 \\
5\end{array}$ & $\begin{array}{l}1.6 \\
43\end{array}$ & $\begin{array}{l}3.4 \\
166\end{array}$ & $\begin{aligned} 5.0 & \\
167 & \end{aligned}$ \\
\hline Anterior fovea LM1 & $\begin{array}{l}\% \\
\mathrm{n}\end{array}$ & $\begin{array}{l}0.0 \\
6\end{array}$ & $\begin{array}{l}4.2 \\
53\end{array}$ & $\begin{array}{c}6.2 \\
186\end{array}$ & $\begin{array}{c}12.3 \\
169\end{array}$ \\
\hline Groove pattern LM1 & $\%$ & $\begin{array}{c}77.8 \\
9\end{array}$ & $\begin{array}{l}87.5 \\
56\end{array}$ & $\begin{array}{c}88.9 \\
190\end{array}$ & $\begin{array}{l}92.3 \\
168\end{array}$ \\
\hline Distal trigonid crest LM1 & $\begin{array}{l}\% \\
\mathrm{n}\end{array}$ & $\begin{array}{l}0.0 \\
7\end{array}$ & $\begin{array}{c}1.8 \\
56\end{array}$ & $\begin{array}{c}1.6 \\
189\end{array}$ & $\begin{array}{c}4.1 \\
170\end{array}$ \\
\hline Protostylid LM1 & $\begin{array}{l}\% \\
\mathrm{n}\end{array}$ & $\begin{array}{l}1.8 \\
8\end{array}$ & $\begin{array}{c}3.7 \\
54\end{array}$ & $\begin{array}{c}3.1 \\
195\end{array}$ & $\begin{array}{c}2.6 \\
169\end{array}$ \\
\hline Cusp number LM1 & $\begin{array}{l}\% \\
\mathrm{n}\end{array}$ & $\begin{array}{c}14.3 \\
7\end{array}$ & $\begin{array}{l}5.6 \\
54\end{array}$ & $\begin{array}{c}10.2 \\
192\end{array}$ & $\begin{array}{r}8.3 \\
168\end{array}$ \\
\hline C7 LM1 & $\begin{array}{l}\% \\
\mathrm{n}\end{array}$ & $\begin{array}{l}0.0 \\
8\end{array}$ & $\begin{array}{c}3.9 \\
56\end{array}$ & $\begin{array}{c}5.6 \\
194\end{array}$ & $\begin{array}{r}2.7 \\
171\end{array}$ \\
\hline \multirow[t]{2}{*}{ Groove pattern LM2 } & $\%$ & 70.0 & 78.1 & 81.9 & 78.0 \\
\hline & $\mathrm{n}$ & 10 & 64 & 221 & 182 \\
\hline \multirow[t]{2}{*}{ Distal trigonid crest LM2 } & $\%$ & 0.0 & 0.0 & 1.8 & 8.7 \\
\hline & $\mathrm{n}$ & 9 & 63 & 223 & 183 \\
\hline \multirow[t]{2}{*}{ Protostylid LM2 } & $\%$ & 0.0 & 2.2 & 4.7 & 3.7 \\
\hline & $\mathrm{n}$ & 10 & 65 & 230 & 182 \\
\hline C5 LM2 & $\%$ & 0.0 & 6.9 & 12.3 & 10.4 \\
\hline & $\mathrm{n}$ & 9 & 64 & 232 & 183 \\
\hline Groove pattern LM3 & $\%$ & 12.5 & 21.7 & 20.0 & 17.6 \\
\hline & $\mathrm{n}$ & 8 & 46 & 195 & 119 \\
\hline Distal trigonid crest LM3 & $\%$ & 0.0 & 17.8 & 18.1 & 28.5 \\
\hline & $\mathrm{n}$ & 8 & 45 & 199 & 123 \\
\hline C5 LM3 & $\%$ & 28.6 & 33.2 & 46.3 & 47.2 \\
\hline & $\mathrm{n}$ & 7 & 47 & 197 & 116 \\
\hline C6 LM3 & $\%$ & 0.0 & 4.3 & 8.7 & 8.3 \\
\hline & $\mathrm{n}$ & 7 & 47 & 197 & 116 \\
\hline
\end{tabular}

Table 1 (continued)

\begin{tabular}{lllllc}
\hline Trait & \multicolumn{5}{c}{ Generations } \\
\cline { 2 - 4 } & & $\mathrm{G} 1$ & $\mathrm{G} 2$ & $\mathrm{G} 3$ & $\mathrm{G} 4$ \\
\hline \multirow{2}{*}{ C7 LM3 } & $\%$ & 2.9 & 0.0 & 1.2 & 0.0 \\
& $\mathrm{n}$ & 7 & 46 & 203 & 119 \\
Foramina mentales & $\%$ & 0.0 & 6.3 & 4.1 & 5.2 \\
& $\mathrm{n}$ & 13 & 96 & 294 & 194 \\
Mylohyoid bridge & $\%$ & 23.1 & 19.3 & 16.0 & 9.0 \\
& $\mathrm{n}$ & 13 & 96 & 291 & 188 \\
Mandibular torus & $\%$ & 20.5 & 10.5 & 7.6 & 4.1 \\
& $\mathrm{n}$ & 13 & 95 & 294 & 194 \\
Maxillary torus & $\%$ & 23.1 & 23.9 & 22.9 & 18.4 \\
& $\mathrm{n}$ & 13 & 94 & 292 & 194 \\
\hline
\end{tabular}

These components account for all of the variance. The loading of each variable for the components are also shown. of the PCA that analyzes the Coimbra-identified cranial collections'

generations

Pistal aggensfory ridge (13/23)

$\begin{array}{rrr}\mathrm{r} 0.940 & \mathrm{r}-202 & \mathrm{r}_{0.340} \\ 0.855 & 0.515 & 0.060 \\ -0.875 & 0.482 & -0.033\end{array}$

Distal accessory ridge (33/43)

Winging (11/21)

$\begin{array}{rrr}0.966 & 0.121 & -0.226 \\ 0.098 & -0.869 & -0.484 \\ -0.595 & 0.646 & -0.478\end{array}$

Midline diastema (11/21)

Interruption grooves $(12 / 22)$

Accessory crests (14/24)

Accessory cusps $(15 / 25)$

Accessory crests (15/25)

Carabelli's trait $(16 / 26)$

C5 (16/26)

Mesial marginal accessory tubercles $(16 / 26)$

$-0.595 \quad 0.646$

$\begin{array}{lll}0.796 & 0.594 & -0.114\end{array}$

Hypocone (17/27)

Enamel extensions (18/28)

Lingual cusp variation (34/44)

Lingual cusp variation $(35 / 45)$

Deflecting wrinkle (36/46)

Anterior fovea (36/46)

Groove pattern (36/46)

Distal trigonid crest (36/46)

Protostylid (36/46)

Cusp number (36/46)

C7 (36/46)

Groove pattern (37/47)

Distal trigonid crest (37/47)

Protostylid (37/47)

C5 (37/47)

Groove pattern (38/48)

Distal trigonid crest (38/48)

$\begin{array}{lll}0.839 & 0.544 & 0.014\end{array}$

$\begin{array}{lll}0.416 & 0.862 & 0.289\end{array}$

$\begin{array}{lll}0.975 & 0.189 & 0.121\end{array}$

$\begin{array}{lll}0.944 & 0.204 & 0.260\end{array}$

$\begin{array}{llr}0.944 & 0.204 & 0.260 \\ 0.767 & 0.616 & -0.181\end{array}$

$\begin{array}{lll}0.999 & 0.033 & -0.034\end{array}$

$\begin{array}{lll}0.906 & 0.355 & -0.232\end{array}$

$\begin{array}{lll}0.954 & -0.276 & 0.116\end{array}$

$\begin{array}{lll}-0.615 & 0.673 & -0.410\end{array}$

$\begin{array}{lll}0.977 & 0.206 & 0.055\end{array}$

$\begin{array}{lll}0.952 & 0.267 & -0.147\end{array}$

$\begin{array}{lll}0.984 & -0.137 & -0.116\end{array}$

$\begin{array}{lll}0.910 & 0.227 & -0.347\end{array}$

$\begin{array}{lll}0.477 & -0.853 & -0.212\end{array}$

$\begin{array}{lll}-0.616 & 0.563 & 0.551\end{array}$

$\begin{array}{lll}0.674 & -0.663 & 0.325\end{array}$

$\begin{array}{lll}0.826 & -0.501 & 0.257\end{array}$

$\begin{array}{lll}0.769 & 0.615 & -0.177\end{array}$

$\begin{array}{lll}0.909 & -0.211 & 0.359\end{array}$

$\begin{array}{lll}0.933 & -0.246 & 0.264\end{array}$

$\begin{array}{lll}0.612 & -0.781 & -0.127\end{array}$

$\begin{array}{lll}0.973 & -0.047 & -0.225\end{array}$

$\begin{array}{lll}0.962 & -0.101 & 0.253\end{array}$

C6 (38/48)

C7 (38/48)

Foramina mentales

Mylohyoid bridge

Mandibular torus

Eigenvalue

Variance

Total variance

$\begin{array}{rr}-0.804 & 0.327\end{array}$

$\begin{array}{rrr}-0.760 & -0.510 & -0.403 \\ -0.941 & -0.327 & 0.091\end{array}$

$\begin{array}{lll}-0.994 & 0.092 & 0.050\end{array}$

$\begin{array}{lll}25.058 & 8.248 & 2.693\end{array}$

$\begin{array}{lll}69.6 & 22.6 & 7.5\end{array}$

$\begin{array}{lrr}69.6 & 92.5 & 100.0\end{array}$

Highlighted figures represent strong positive $(>0.5$; italic) and strong negative $(<-0.5$; boldface) loadings within each component

PC principal component 
The first principal component, PC1 (69.6\% variance), features 25 traits with strong positive loadings $(>0.5)$. These loadings indicate frequencies for those traits tend to increase over time (or with each generation). Strong negative loadings $(<-0.5)$, on the other hand, show a tendency for decreasing frequencies. These loadings are present in eight traits. Only three traits do not possess strong loadings.

PC2 (22.6\% variance) includes nine traits with strong positive loadings and seven with strong negative loadings. PC3 (7.5\% variance) shows only one strong positive loading, LM1 cusp number.

Figures 1 and 2 provide scatterplots of the component scores for the sample centroids of the four generations and encompass 92.5 and $100 \%$ of the variance, respectively. $\mathrm{G} 1$ is relatively distant to the other generation subsamples along PC1, while G2, G3, and G4 are nearly equidistant (factor distances of around 0.5 along PC1). All subsamples are chronologically distributed along PC1. PC2 shows the proximity between $\mathrm{G} 1$ and $\mathrm{G} 4$ as well as between G2 and G3. The third component (PC3) separates G3 from the other generations.

Table 3 provides the MMD (with Freeman and Tukey's correction) distance matrix and respective significance ( $p$ value). All biodistances are very low $(<0.1)$. Only the divergences between $\mathrm{G} 2$ and $\mathrm{G} 4$ and between G3 and G4 are statistically significant. This is a consequence of low sample size, particularly with regard to the biodistances involving G1, as well as by the low divergences which are greatest between G2 and G4 (0.062), and even this distance is very small.
Biological affinities among places of birth

Several subsamples were compared to assess the impact of the presence of individuals born in diverse regions and countries upon the full sample as a dental morphology reference for the late modern/early contemporary residents in Portugal. The subsamples include members of three large Portuguese regions, foreigners, all Portuguese individuals regardless of region, and the full sample. All 61 traits were included (see Table 4).

The eigenvalues, variances, and trait loadings of each component calculated by PCA (including the mentioned samples and all their traits' expressions) are presented in Table 5. The three factors represent $98.3 \%$ of the variation. PC1 $(43.4 \%$ variance) has 22 traits with strong positive loadings and 13 with strong negative loadings. These strong positive and negative loadings correspond to traits where the south and foreign subsamples present the lowest and the highest frequencies, respectively. So, PCA results place these two samples in the extremes of PC1 in correspondence to their phenetic variation.

On PC2 (38.8\% variance), there are 17 traits with strong positive loadings and 12 with strong negative loadings. These correspond to traits with strong expression from foreigners and weak expression from southern Portuguese, and vice versa, respectively.

PC3 (16.1\% variance) presents 11 traits with loadings above 0.5 and 2 traits with loadings below -0.5 . These traits correspond to very low and very high expressions among members of the northern subsample.

Figure 3 (82.2\% of variance) and Fig. 4 (98.3\% of variance) depict the distributions of samples along the obtained
Fig. 1 Scatterplot of the first two components among generations of the Coimbra sample. A total of $92.5 \%$ of the variation is

represented

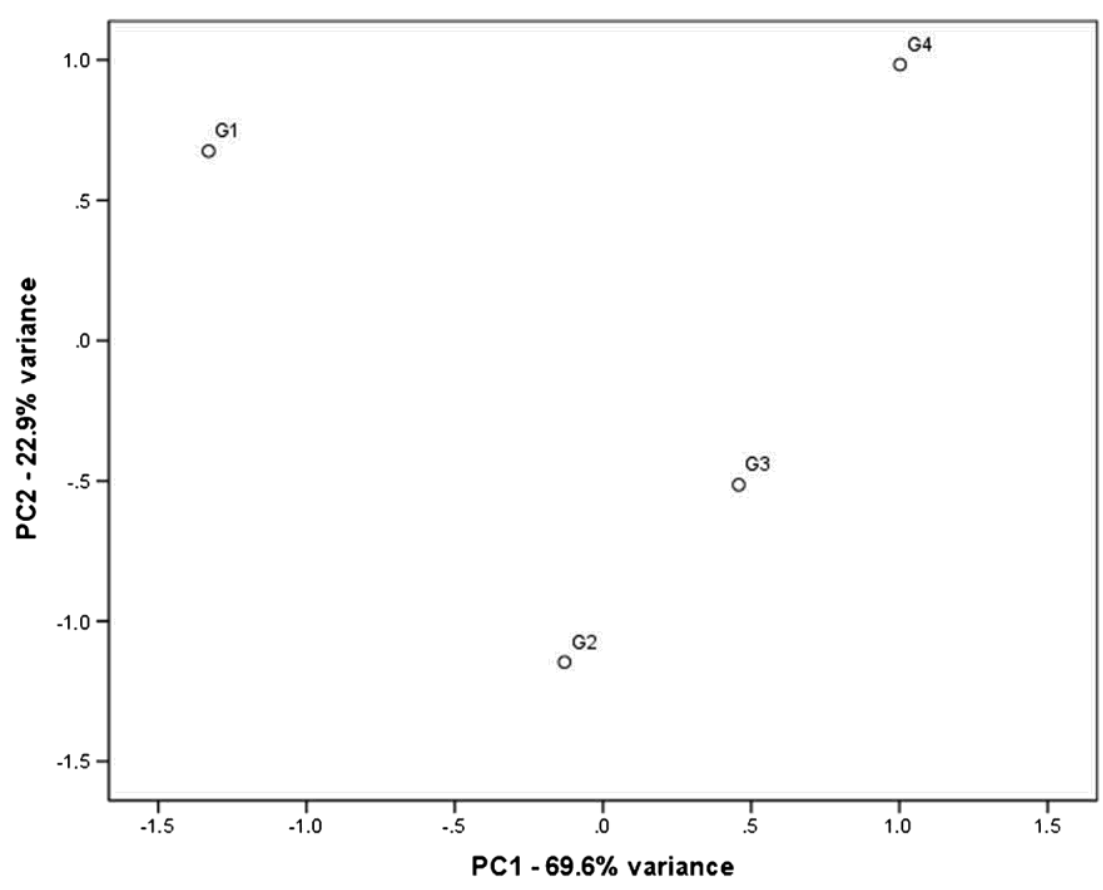




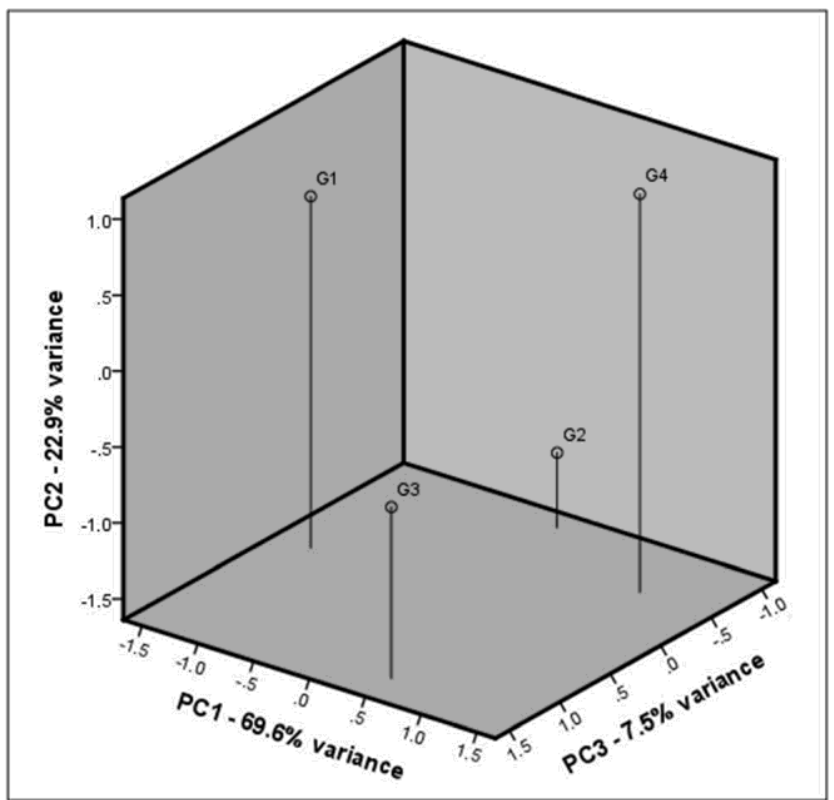

Fig. 2 Scatterplot of the three components among generations of the Coimbra sample. The total variation $(100 \%)$ is represented

components. A cluster of the north, center, Coimbra, and Portuguese subsamples is clear in Fig. 3. PC1 clearly separates southerners and foreigners from the aforementioned cluster. PC2 presents southerners and foreigners on either extreme of the distribution. Finally, PC3 separates the former cluster, since along that component, northerners appear further from the remaining subsamples.

It should be noted the apparently, large graphical distances between the cluster, foreigners, and southerners are most likely due to a lack of outliers (biologically distant samples). Such outliers would function as a scale and allow for a finer visual representation of biological affinities. This is because the plotted PCA maximizes the variation found within the samples regardless of their actual biodistance.

Table 6 displays the MMD results and $\mathrm{p}$ values (using the uncorrected formula, since using the correction produced negative MMD values, due to small sample sizes). Once again, all biodistances are very low. The highest separates northerners from foreigners but is still very small $(0.107)$. The lowest

Table 3 Matrix of the MMD that analyzes the Coimbra sample generations

\begin{tabular}{lllll}
\hline Samples & G1 & G2 & G3 & G4 \\
\hline G1 & & $-0.082^{\mathrm{a}}$ & $-0.078^{\mathrm{a}}$ & $-0.060^{\mathrm{a}}$ \\
G2 & $1^{\mathrm{b}}$ & & $0.010^{\mathrm{a}}$ & $0.062^{\mathrm{a}}$ \\
G3 & $1^{\mathrm{b}}$ & $0.075^{\mathrm{b}}$ & & $0.016^{\mathrm{a}}$ \\
G4 & $1^{\mathrm{b}}$ & $0^{\mathrm{b}}$ & $<0.001^{\mathrm{b}}$ & \\
\hline
\end{tabular}

${ }^{\text {a }}$ Biodistance results between each pair of samples

${ }^{\mathrm{b}}$ Significance of the MMD divergence is between the full sample $(\mathrm{C}-\mathrm{Pt})$ and the Portuguese-born subsample $(<0.001)$.

Some samples are separated by biodistances below 0.01, such as (1) center and north, (2) Portuguese and north, (3) center and Portuguese, (4) C-Pt and center, and (5) north and $\mathrm{C}-\mathrm{Pt}$, besides the already mentioned (6) Portuguese and C-Pt biodistance. Other samples present divergences near 0.1 . These are (1) north and south, (2) south and center, (3) foreigners and center, (4) south and foreigners, (5) Portuguese and south, (6) foreigners and Portuguese, (7) south and C-Pt, and (8) foreigners and C-Pt. South and foreign are the most divergent samples, while north, center, Portuguese, and C-Pt are much alike.

Almost all distances were significant $(\mathrm{p}<0.05)$, with two exceptions: southerners and foreigners $(p=0.237)$, likely due to their very small sample sizes, and C-Pt and Portuguese $(p=0.986)$, probably because of their great similarity, since nonsignificant MMD results can indicate the samples were drawn from the same biological population (see Harris and Sjøvold 2004). Since these samples overlap (as they share most individuals), their proximity and high $\mathrm{p}$ value were expected.

\section{Discussion}

\section{Biological affinities among generations}

The equidistant distribution of subsamples seen on the plotted PCA results (Figs. 1 and 2) and the very small biodistances measured by MMD analysis (Table 3) suggest there are no major genetic distinctions between these generations. The chronological distribution of the different generations are likely related to the steady increase in occlusal wear (results not shown) the older the generation. This increase in wear can impact some trait frequencies that tend to be decreased, according to the results of studies on the effect of occlusal wear on dental morphology scoring (Burnett et al. 2013; Marado 2014). Occlusal wear affects trait frequencies even when the wear level is low to moderate and when considering teeth with excessive wear as missing. Burnett et al. (2013) suggest avoiding the comparison of samples with different mean wear levels when possible. Unfortunately, that maneuver would have precluded the present analysis.

The PCA analysis placed G1 as the most different sample, with its greater distance on the most representative component (PC1, 69.6\% variance). As for the MMD, null distances between G1 and the other generations were found. This difference occurred because the PCA does not consider sample size, while the MMD values it. G1 sample size does not allow any clear conclusions to be drawn on that subsample, which should be disregarded. The other generations (G2 to G4) seem to be very phenotypically close. 
Table 4 Trait expressions for the Coimbra-identified cranial collections' subsamples

\begin{tabular}{|c|c|c|c|c|c|c|c|}
\hline Traits & & North & Center & South & Foreign & Portuguese & $\mathrm{C}-\mathrm{Pt}$ \\
\hline \multirow[t]{2}{*}{ Distal accessory ridge LC } & $\%$ & 10.0 & 13.2 & 14.0 & 8.9 & 12.6 & 12.5 \\
\hline & $\mathrm{n}$ & 84 & 402 & 10 & 9 & 502 & 511 \\
\hline \multirow[t]{2}{*}{ Distal accessory ridge UC } & $\%$ & 21.5 & 28.2 & 26.7 & 31.4 & 26.7 & 26.8 \\
\hline & $\mathrm{n}$ & 79 & 368 & 9 & 7 & 462 & 469 \\
\hline \multirow[t]{2}{*}{ Shoveling LI1 } & $\%$ & 0.0 & 0.5 & 0.0 & 0.0 & 0.4 & 0.4 \\
\hline & $\mathrm{n}$ & 56 & 291 & 5 & 7 & 356 & 363 \\
\hline \multirow[t]{2}{*}{ Winging UI1 } & $\%$ & 1.2 & 4.0 & 6.3 & 0.0 & 3.6 & 3.6 \\
\hline & $\mathrm{n}$ & 63 & 308 & 4 & 6 & 379 & 385 \\
\hline \multirow[t]{2}{*}{ Shoveling UI1 } & $\%$ & 3.5 & 2.6 & 11.1 & 0.0 & 2.8 & 2.7 \\
\hline & $\mathrm{n}$ & 38 & 213 & 3 & 6 & 256 & 262 \\
\hline \multirow[t]{2}{*}{ Double shoveling UI1 } & $\%$ & 0.0 & 0.8 & 5.6 & 0.0 & 0.7 & 0.7 \\
\hline & $\mathrm{n}$ & 37 & 203 & 3 & 5 & 245 & 250 \\
\hline \multirow[t]{2}{*}{ Interruption grooves UI1 } & $\%$ & 6.9 & 5.2 & 0.0 & 0.0 & 5.4 & 5.3 \\
\hline & $\mathrm{n}$ & 58 & 287 & 4 & 6 & 352 & 358 \\
\hline \multirow[t]{2}{*}{ Midline diastema } & $\%$ & 6.9 & 10.6 & 0.0 & 20.0 & 10.3 & 10.6 \\
\hline & $\mathrm{n}$ & 29 & 179 & 3 & 5 & 213 & 218 \\
\hline \multirow{2}{*}{ Interruption grooves UI2 } & $\%$ & 12.3 & 17.8 & 40.0 & 22.2 & 17.2 & 17.3 \\
\hline & $\mathrm{n}$ & 81 & 353 & 5 & 9 & 443 & 452 \\
\hline \multirow[t]{2}{*}{ Peg incisor UI2 } & $\%$ & 2.2 & 2.3 & 0.0 & 5.6 & 2.3 & 2.3 \\
\hline & $\mathrm{n}$ & 89 & 384 & 5 & 9 & 483 & 492 \\
\hline \multirow[t]{2}{*}{ Accessory cusp UP3 } & $\%$ & 0.0 & 1.4 & 0.0 & 0.0 & 1.1 & 1.1 \\
\hline & $\mathrm{n}$ & 80 & 357 & 8 & 6 & 449 & 455 \\
\hline \multirow[t]{2}{*}{ Accessory ridge UP3 } & $\%$ & 1.3 & 6.2 & 0.0 & 20.0 & 5.1 & 5.3 \\
\hline & $\mathrm{n}$ & 80 & 357 & 7 & 5 & 448 & 453 \\
\hline Tricuspid premolar UP3 & $\%$ & 0.0 & 0.3 & 0.0 & 0.0 & 0.2 & 0.2 \\
\hline & $\mathrm{n}$ & 87 & 385 & 9 & 7 & 486 & 493 \\
\hline Odontome UP3 & $\%$ & 1.2 & 0.3 & 0.0 & 0.0 & 0.4 & 0.4 \\
\hline & $\mathrm{n}$ & 86 & 381 & 9 & 6 & 481 & 487 \\
\hline Accessory cusp UP4 & $\%$ & 5.1 & 3.0 & 0.0 & 0.0 & 3.3 & 3.2 \\
\hline & $\mathrm{n}$ & 79 & 367 & 10 & 7 & 459 & 466 \\
\hline Accessory ridge UP4 & $\%$ & 16.0 & 27.7 & 30.0 & 16.7 & 25.7 & 25.6 \\
\hline & $\mathrm{n}$ & 81 & 368 & 10 & 6 & 463 & 469 \\
\hline Tricuspid premolar UP4 & $\%$ & 0.0 & 0.3 & 0.0 & 0.0 & 0.2 & 0.2 \\
\hline & $\mathrm{n}$ & 88 & 387 & 10 & 7 & 489 & 496 \\
\hline Odontome UP4 & $\%$ & 1.2 & 0.0 & 0.0 & 0.0 & 0.2 & 0.2 \\
\hline & $\mathrm{n}$ & 86 & 382 & 10 & 7 & 482 & 489 \\
\hline Carabelli UM1 & $\%$ & 12.8 & 16.4 & 20.6 & 19.1 & 15.7 & 15.8 \\
\hline & $\mathrm{n}$ & 87 & 373 & 9 & 6 & 473 & 479 \\
\hline C5 UM1 & $\%$ & 1.2 & 2.7 & 4.4 & 8.0 & 2.4 & 2.5 \\
\hline es ontit & $\mathrm{n}$ & 86 & 374 & 9 & 5 & 473 & 478 \\
\hline Mesial marginal accessory tubercle UM1 & $\%$ & 1.2 & 5.3 & 0.0 & 25.0 & 4.4 & 4.6 \\
\hline & $\mathrm{n}$ & 83 & 357 & 9 & 4 & 453 & 457 \\
\hline Enamel extension UM1 & $\%$ & 5.3 & 2.8 & 0.0 & 0.0 & 3.2 & 3.1 \\
\hline & $\mathrm{n}$ & 63 & 275 & 7 & 5 & 348 & 353 \\
\hline C4 UM2 & $\%$ & 49.8 & 51.3 & 50.0 & 31.5 & 50.9 & 50.6 \\
\hline & $\mathrm{n}$ & 93 & 413 & 10 & 9 & 521 & 530 \\
\hline Enamel extension UM2 & $\%$ & 16.4 & 14.7 & 8.3 & 0.0 & 14.8 & 14.6 \\
\hline & $\mathrm{n}$ & 71 & 330 & 8 & 6 & 413 & 419 \\
\hline Enamel extension UM3 & $\%$ & 7.7 & 4.0 & 0.0 & 0.0 & 4.5 & 4.5 \\
\hline & $\mathrm{n}$ & 39 & 177 & 2 & 1 & 220 & 221 \\
\hline Parastyle UM3 & $\%$ & 0.6 & 1.5 & 0.0 & 0.0 & 1.3 & 1.3 \\
\hline & $\mathrm{n}$ & 56 & 231 & 5 & 2 & 294 & 296 \\
\hline Shoveling LI2 & $\%$ & 0.9 & 0.5 & 0.0 & 0.0 & 0.5 & 0.5 \\
\hline & $\mathrm{n}$ & 72 & 341 & 9 & 8 & 426 & 434 \\
\hline Odontome LP3 & $\%$ & 0.0 & 0.0 & 0.0 & 0.0 & 0.0 & 0.0 \\
\hline & $\mathrm{n}$ & 94 & 416 & 11 & 8 & 527 & 535 \\
\hline Lingual cusp variation LP3 & $\%$ & 8.1 & 10.8 & 10.1 & 12.5 & 6.3 & 6.4 \\
\hline & $\mathrm{n}$ & 93 & 408 & 11 & 8 & 518 & 526 \\
\hline Odontome LP4 & $\%$ & 0.0 & 0.3 & 0.0 & 0.0 & 0.2 & 0.2 \\
\hline & $\mathrm{n}$ & 90 & 396 & 11 & 8 & 503 & 511 \\
\hline Lingual cusp variation LP4 & $\%$ & 21.7 & 20.7 & 20 & 6.9 & 9.4 & 9.3 \\
\hline & $\mathrm{n}$ & 89 & 389 & 10 & 8 & 494 & 502 \\
\hline Deflecting wrinkle LM1 & $\%$ & 2.0 & 4.3 & 0.0 & 5.6 & 3.8 & 3.8 \\
\hline & $\mathrm{n}$ & 66 & 299 & 8 & 6 & 378 & 384 \\
\hline Anterior fovea LM1 & $\%$ & 7.0 & 8.4 & 9.4 & 14.3 & 8.2 & 8.3 \\
\hline & $\mathrm{n}$ & 71 & 326 & 8 & 7 & 410 & 417 \\
\hline
\end{tabular}




\begin{tabular}{|c|c|c|c|c|c|c|c|}
\hline Traits & & North & Center & South & Foreign & Portuguese & C-Pt \\
\hline \multirow[t]{2}{*}{ Groove pattern LM1 } & $\%$ & 87.8 & 89.7 & 100 & 100 & 89.7 & 89.9 \\
\hline & $\mathrm{n}$ & 74 & 331 & 9 & 7 & 419 & 426 \\
\hline \multirow[t]{2}{*}{ Distal trigonid crest LM1 } & $\%$ & 1.4 & 3.0 & 0.0 & 0.0 & 2.6 & 2.6 \\
\hline & $\mathrm{n}$ & 74 & 329 & 9 & 7 & 417 & 424 \\
\hline \multirow[t]{2}{*}{ Protostylid LM1 } & $\%$ & 2.5 & 3.0 & 4.8 & 2.0 & 2.9 & 2.9 \\
\hline & $\mathrm{n}$ & 75 & 334 & 9 & 7 & 422 & 429 \\
\hline \multirow[t]{2}{*}{ MMPT LM1 } & $\%$ & 0.0 & 1.0 & 0.0 & 0.0 & 0.8 & 0.7 \\
\hline & $\mathrm{n}$ & 74 & 330 & 8 & 7 & 417 & 424 \\
\hline \multirow[t]{2}{*}{ C5 LM1 } & $\%$ & 72.2 & 74.3 & 68.9 & 82.9 & 73.8 & 73.9 \\
\hline & $\mathrm{n}$ & 72 & 330 & 9 & 7 & 416 & 423 \\
\hline \multirow[t]{2}{*}{ C6 LM1 } & $\%$ & 0.0 & 0.6 & 0.0 & 2.9 & 0.5 & 0.5 \\
\hline & $\mathrm{n}$ & 72 & 331 & 9 & 7 & 417 & 424 \\
\hline \multirow[t]{2}{*}{ C7 LM1 } & $\%$ & 3.8 & 4.4 & 8.9 & 0.0 & 4.3 & 4.3 \\
\hline & $\mathrm{n}$ & 74 & 337 & 9 & 7 & 425 & 432 \\
\hline \multirow{2}{*}{ Groove pattern LM2 } & $\%$ & 83.5 & 78.9 & 88.9 & 71.4 & 79.9 & 79.8 \\
\hline & $\mathrm{n}$ & 85 & 374 & 9 & 7 & 473 & 480 \\
\hline \multirow[t]{2}{*}{ Distal trigonid crest LM2 } & $\%$ & 3.5 & 4.5 & 0.0 & 0.0 & 4.2 & 4.2 \\
\hline & $\mathrm{n}$ & 85 & 375 & 9 & 7 & 474 & 481 \\
\hline \multirow[t]{2}{*}{ Protostylid LM2 } & $\%$ & 3.9 & 4.0 & 3.6 & 1.8 & 3.9 & 3.9 \\
\hline & $\mathrm{n}$ & 85 & 383 & 8 & 8 & 482 & 490 \\
\hline \multirow[t]{2}{*}{ MMPT LM2 } & $\%$ & 1.3 & 1.5 & 0.0 & 0.0 & 1.4 & 1.4 \\
\hline & $\mathrm{n}$ & 85 & 383 & 9 & 8 & 483 & 491 \\
\hline \multirow[t]{2}{*}{ C5 LM2 } & $\%$ & 12.6 & 13.8 & 0.0 & 25.7 & 13.1 & 13.3 \\
\hline & $\mathrm{n}$ & 86 & 384 & 8 & 7 & 484 & 491 \\
\hline \multirow[t]{2}{*}{ C6 LM2 } & $\%$ & 0.5 & 0.4 & 0.0 & 0.0 & 0.4 & 0.4 \\
\hline & $\mathrm{n}$ & 86 & 384 & 8 & 7 & 484 & 491 \\
\hline \multirow[t]{2}{*}{ C7 LM2 } & $\%$ & 0.0 & 0.2 & 0.0 & 0.0 & 0.2 & 0.2 \\
\hline & $\mathrm{n}$ & 86 & 389 & 9 & 6 & 490 & 496 \\
\hline \multirow[t]{2}{*}{ Groove pattern LM3 } & $\%$ & 19.0 & 19.0 & 33.3 & 20.0 & 19.5 & 19.5 \\
\hline & $\mathrm{n}$ & 63 & 294 & 3 & 5 & 364 & 369 \\
\hline \multirow[t]{2}{*}{ Distal trigonid crest LM3 } & $\%$ & 15.6 & 22.2 & 0.0 & 25.0 & 21.0 & 21.0 \\
\hline & $\mathrm{n}$ & 64 & 302 & 3 & 4 & 372 & 376 \\
\hline \multirow[t]{2}{*}{ Protostylid LM3 } & $\%$ & 2.1 & 1.6 & 33.3 & 0.0 & 2.2 & 2.1 \\
\hline & $\mathrm{n}$ & 60 & 275 & 3 & 5 & 341 & 346 \\
\hline \multirow[t]{2}{*}{ MMPT LM3 } & $\%$ & 11.5 & 11.6 & 23.8 & 21.4 & 11.6 & 11.7 \\
\hline & $\mathrm{n}$ & 62 & 280 & 3 & 4 & 349 & 353 \\
\hline \multirow[t]{2}{*}{ C5 LM3 } & $\%$ & 41.0 & 45.1 & 66.7 & 40.0 & 44.7 & 44.7 \\
\hline & $\mathrm{n}$ & 60 & 297 & 3 & 4 & 364 & 368 \\
\hline \multirow[t]{2}{*}{ C6 LM3 } & $\%$ & 5.7 & 8.1 & 0.0 & 30.0 & 7.6 & 7.8 \\
\hline & $\mathrm{n}$ & 60 & 297 & 3 & 4 & 364 & 368 \\
\hline C7 LM3 & $\%$ & 0.0 & 0.9 & 0.0 & 0.0 & 0.7 & 0.7 \\
\hline & $\mathrm{n}$ & 62 & 304 & 3 & 3 & 373 & 376 \\
\hline Foramina mentales & $\%$ & 3.7 & 4.7 & 16.7 & 0.0 & 4.7 & 4.7 \\
\hline & $\mathrm{n}$ & 107 & 466 & 12 & 9 & 591 & 600 \\
\hline Mylohyoid bridge & $\%$ & 11.4 & 15.4 & 4.2 & 27.8 & 14.3 & 14.5 \\
\hline & $\mathrm{n}$ & 105 & 459 & 12 & 9 & 582 & 591 \\
\hline Mandibular torus & $\%$ & 6.2 & 7.2 & 18.2 & 11.1 & 7.2 & 7.2 \\
\hline & $\mathrm{n}$ & 107 & 466 & 11 & 9 & 590 & 599 \\
\hline Palatine torus & $\%$ & 21.5 & 21.6 & 25.0 & 22.2 & 21.6 & 21.6 \\
\hline & $\mathrm{n}$ & 107 & 463 & 12 & 9 & 587 & 596 \\
\hline
\end{tabular}

C-Pt Coimbra (Portugal) full sample

Finally, most traits seem to show an increase in expression, as noted for the PC1 loadings. Bocquet-Appel (1984) found cranial trait variation in males of the Coimbra samples (divided in 20-year-long generations). The author justified these changes in cranial morphology with an environmental factor, fluctuating wheat prices. Weisensee and Jantz (2011) found craniofacial secular changes in the New Lisbon-identified collection (early nineteenth to mid-twentieth centuries) and related them to developmental plasticity in the context of demographic shifts (decrease in mortality and fertility coupled with greater longevity), excluding gene flow into Portugal as a factor. The generational increase in dental trait frequencies (assuming a different pattern then cranial morphology changes) should not be related to environmental factors (less pertinent to dental morphology) and most likely does not equate to a secular trend, since results are probably affected by differences in dental wear (results not shown). The present Portuguese sample displays biological continuity—as testified by uniparental genetic markers (Pereira 
of the PCA that analyzes the Coimbra-identified cranial collections' subsamples

\begin{tabular}{|c|c|c|c|}
\hline Trait (tooth) & $\mathrm{PC} 1$ & $\mathrm{PC} 2$ & PC3 \\
\hline Distal accessory ridge (13/23) & 0.174 & 0.784 & 0.596 \\
\hline Distal accessory ridge (33/43) & -0.515 & -0.502 & 0.694 \\
\hline Shoveling (31/41) & 0.709 & -0.041 & 0.704 \\
\hline Winging (11/21) & -0.003 & 0.869 & 0.494 \\
\hline Shoveling $(11 / 21)$ & -0.360 & 0.932 & -0.027 \\
\hline Double shoveling (11/21) & -0.539 & 0.821 & 0.187 \\
\hline Interruption grooves $(11 / 21)$ & 0.976 & 0.009 & -0.219 \\
\hline Midline diastema (11/21) & -0.032 & -0.986 & 0.159 \\
\hline Interruption grooves $(12 / 22)$ & -0.787 & 0.566 & 0.246 \\
\hline Peg incisor $(12 / 22)$ & -0.154 & -0.988 & -0.031 \\
\hline Accessory cusps $(14 / 24)$ & 0.708 & -0.041 & 0.705 \\
\hline Accessory crests $(14 / 24)$ & -0.399 & -0.897 & 0.192 \\
\hline Tricuspid premolars (14/24) & 0.692 & -0.040 & 0.709 \\
\hline Odontome (14/24) & 0.665 & 0.039 & -0.744 \\
\hline Accessory cusps $(15 / 25)$ & 0.923 & 0.018 & -0.383 \\
\hline Accessory crests $(15 / 25)$ & 0.047 & 0.679 & 0.733 \\
\hline Tricuspid premolars $(15 / 25)$ & 0.692 & -0.040 & 0.709 \\
\hline Odontome $(15 / 25)$ & 0.429 & 0.048 & -0.902 \\
\hline Carabelli's trait (16/26) & -0.868 & 0.149 & 0.474 \\
\hline C5 $(16 / 26)$ & -0.853 & -0.480 & 0.203 \\
\hline Mesial marginal accessory tubercles (16/26) & -0.485 & -0.867 & 0.113 \\
\hline Enamel extensions $(16 / 26)$ & 0.897 & 0.022 & -0.442 \\
\hline Hypocone (17/27) & 0.660 & 0.746 & 0.092 \\
\hline Enamel extensions (17/27) & 0.902 & 0.421 & -0.093 \\
\hline Enamel extensions (18/28) & 0.891 & 0.022 & -0.453 \\
\hline Parastyle (18/28) & 0.899 & -0.027 & 0.436 \\
\hline Shoveling (32/42) & 0.890 & 0.023 & -0.451 \\
\hline Lingual cusp variation $(34 / 44)$ & -0.686 & -0.300 & 0.077 \\
\hline Odontome $(35 / 45)$ & 0.692 & -0.040 & 0.709 \\
\hline Lingual cusp variation $(35 / 45)$ & 0.149 & 0.632 & -0.329 \\
\hline Deflecting wrinkle (36/46) & 0.180 & -0.921 & 0.345 \\
\hline Anterior fovea $(36 / 46)$ & -0.774 & -0.608 & 0.173 \\
\hline Groove pattern (36/46) & -0.989 & -0.005 & 0.146 \\
\hline Distal trigonid crest (36/46) & 0.924 & -0.024 & 0.382 \\
\hline Protostylid (36/46) & -0.307 & 0.922 & 0.236 \\
\hline MMPT (36/46) & 0.703 & -0.040 & 0.706 \\
\hline C5 (36/46) & -0.262 & -0.959 & 0.105 \\
\hline C6 (36/46) & -0.499 & -0.853 & 0.154 \\
\hline C7 (36/46) & -0.042 & 0.991 & 0.129 \\
\hline Groove pattern $(37 / 47)$ & 0.033 & 0.975 & -0.221 \\
\hline Distal trigonid crest (37/47) & 0.990 & -0.010 & 0.138 \\
\hline Protostylid (37/47) & 0.745 & 0.664 & 0.049 \\
\hline MMPT (37/47) & 0.998 & -0.006 & 0.065 \\
\hline C5 (37/47) & 0.020 & -0.999 & -0.013 \\
\hline C6 (37/47) & 0.983 & 0.007 & -0.184 \\
\hline C7 (37/47) & 0.714 & -0.041 & 0.683 \\
\hline Groove pattern $(38 / 48)$ & -0.670 & 0.739 & 0.066 \\
\hline Distal trigonid crest (38/48) & 0.424 & -0.884 & 0.198 \\
\hline Protostylid (38/48) & -0.581 & 0.812 & 0.046 \\
\hline MMPT (38/48) & -0.990 & 0.134 & 0.030 \\
\hline C5 (38/48) & -0.491 & 0.847 & 0.204 \\
\hline C6 (38/48) & -0.387 & -0.921 & 0.036 \\
\hline C7 (38/48) & 0.707 & -0.041 & 0.706 \\
\hline Foramina mentales & -0.352 & 0.928 & 0.123 \\
\hline Mylohyoid bridge & -0.142 & -0.982 & 0.123 \\
\hline Mandibular torus & -0.865 & 0.487 & 0.122 \\
\hline Maxillary torus & -0.760 & 0.645 & 0.074 \\
\hline Eigenvalue & 24.742 & 22.082 & 9.179 \\
\hline Variance (\%) & 43.4 & 38.8 & 16.1 \\
\hline Total variance (\%) & 43.4 & 82.2 & 98.3 \\
\hline
\end{tabular}

Highlighted figures represent strong positive $(>0.5$; italic) and strong negative $(<-0.5$; boldface) loadings within each component gene frequency through time are detected during this period of little over a century.

\section{Biological affinities among places of birth}

The cluster (including north, center, Portuguese, and C-Pt) identified with PCA (Table 5, Figs. 3 and 4) was readily reproduced by MMD (Table 6), since the same subsamples are the most similar. The remaining subsamples (south and foreigners) were still not very divergent when compared to the others. Their overall phenetic proximity is demonstrated by how the Portuguese (which includes southerners) and C-Pt (full sample that includes foreigners) are the closest samples on both analyses (PCA and MMD).

The biological divergence between the Portuguese and foreigners on the PCA and MMD (0.092) is small and similar to the affinities of south and either of the remaining regional subsamples (north and center). The foreigners included are at least not biologically different enough to produce any noticeable divergences between the Portuguese-born individuals and the full sample (C-Pt), which includes foreign-born individuals.

Genetic markers indicate Iberian isolation in relation to other European populations, with a low number of common ancestors. This may be justified by isolation by distance or due to the Pyrenees, since the Iberian samples have many common ancestors among themselves (Ralph and Coop 2013). While this Iberian genetic isolation could be indicative of a more likely genetic deviation of the foreign subsample from the full Coimbra collections' sample, most of the foreigners (five of nine) are Spanish. The shared common ancestors between the Portuguese and Spanish peoples and the possible familial ties between the foreigners and the Portuguese in the present sample may account for the limited biological distinction between them.

When possible, regional distinctions are analyzed, the center and north regions present great affinity, and only the south subsample is slightly deviated from the others. Yet, it is still phenotypically similar. This indicates the Portuguese are likely biologically homogeneous, despite the migrations into Portugal across time. Further research should analyze the phenetic impact of migrations such as the one from North Africa and Arabia during the Islamic period, which shows a great genetic impact in the male ancestry of Iberia (Adams et al. 2008; Regueiro et al. 2015). North African gene flow into Iberia could have started in prehistory (Martiniano et al. 2013; Brandt et al. 2014), despite difficulty in detecting such ancient genetic processes (Adams et al. 2008) and lack of direct evidence (Sampietro et al. 2005).

Uniparental genetic markers show great homogeneity in Portugal. Y chromosome analysis shows only the exception of Alentejo (region in the south presenting a greater number of 
Fig. 3 Scatterplot of the first two components among the Portuguese-born individuals, the foreign-born individuals, the complete Coimbra sample, and $82.2 \%$ of the variation is represented. Cent central Portugal, C-Pt Coimbra (Portugal) full sample, Frgn individuals born in foreign Port Portuguese-born individuals, Sout southern Portugal the Portuguese regions. A total of countries, Nort northern Portugal,

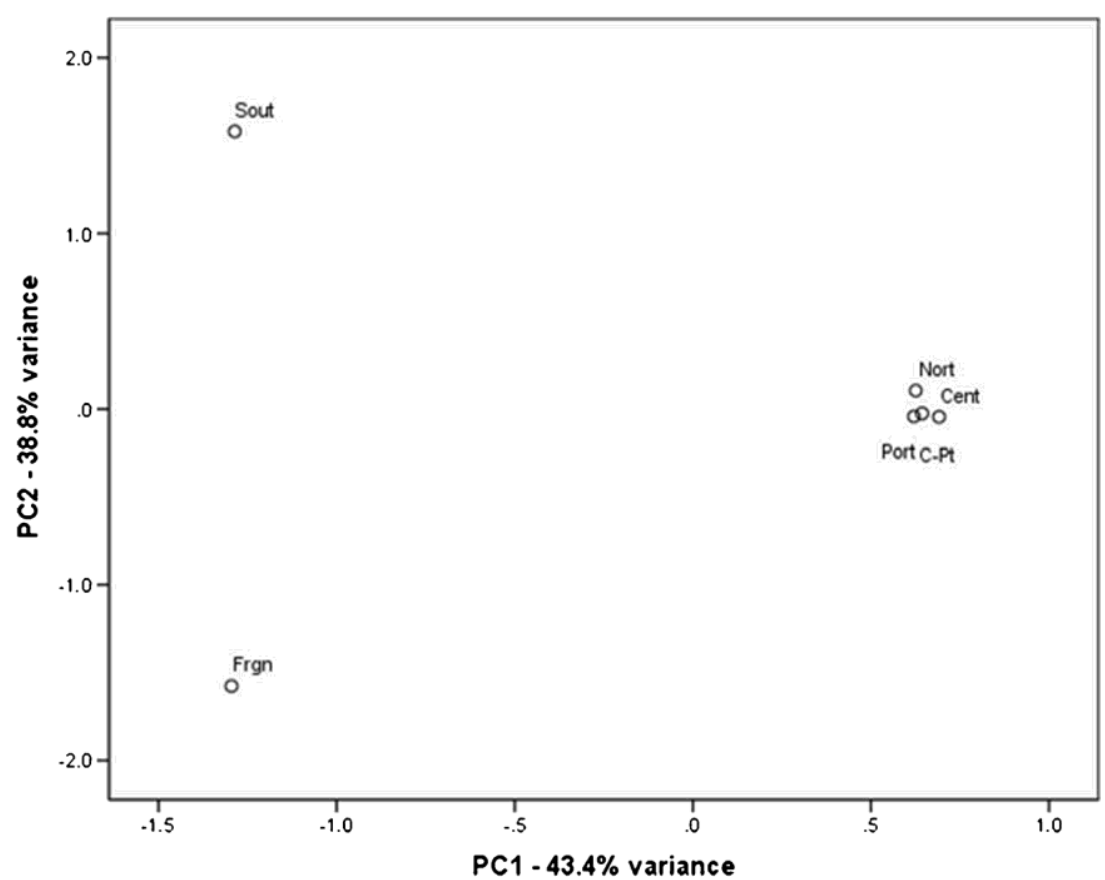

recent lineages and genetic diversity) (Beleza et al. 2006). Maternal markers (mtDNA) also show an exception, since a North African haplogroup is more present in northern Portugal (Pereira et al. 2000). Even linguistic isolates like the Mirandese speakers in innermost northern Portugal (Mairal et al. 2013), or important trade centers like Mértola (Pereira et al. 2006), display only small genetic differences to the overall biological homogeneity in Iberia.

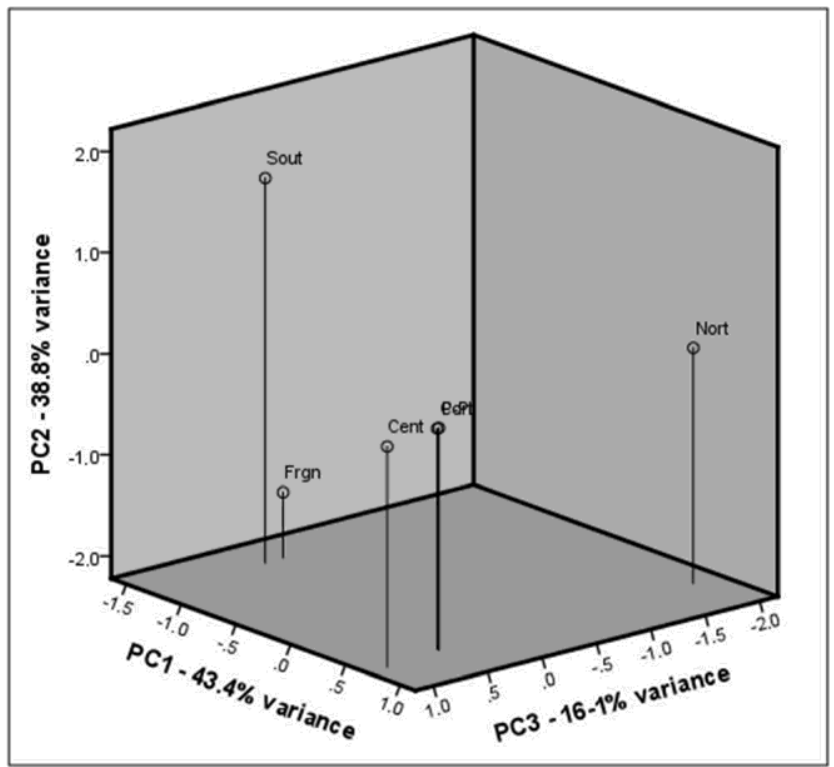

Fig. 4 Scatterplot of the three components among the Portuguese-born individuals, the foreign-born individuals, the complete Coimbra sample, and the Portuguese regions. A total of $98.3 \%$ of the variation is represented. Cent central Portugal, C-Pt Coimbra (Portugal) full sample, Frgn individuals born in foreign countries, Nort northern Portugal, Port Portuguese-born individuals, Sout southern Portugal
In fact, the nearly constant gene flow into Iberia found for prehistoric and historic periods was of relatively little impact, contributing to greater genetic variation, yet not to genetic discontinuities in either chronological or geographical dimensions. The Neolithization process, contrarily to Central Europe, seems to have occurred through the admixture of Near East sea migrants into the local population (Brandt et al. 2014). Celtic language speakers could have spread across the Atlantic zone of Europe from Last Glacial Maximum refugial areas in Southern France and Iberia and not from Central Europe (McEvoy et al. 2004) as hypothesized (Lorrio and Ruiz Zapatero 2005). Biological contact with the Phoenicians has been attested yet is relatively limited (Martiniano et al. 2013). Even the Islamic presence in Iberia, confined to the south for a long period, seems to have not caused major heterogeneity, since the Atlantic and Mediterranean facades are genetically more different to each

Table 6 Matrix of the MMD that analyzes the Coimbra collections' subsamples

\begin{tabular}{lcccccc}
\hline & North & Center & South & Foreign & Portuguese & C-Pt \\
\hline North & & $0.010^{\mathrm{a}}$ & $0.091^{\mathrm{a}}$ & $0.107^{\mathrm{a}}$ & $0.009^{\mathrm{a}}$ & $0.009^{\mathrm{a}}$ \\
Center & $0.004^{\mathrm{b}}$ & & $0.088^{\mathrm{a}}$ & $0.087^{\mathrm{a}}$ & $0.003^{\mathrm{a}}$ & $0.003^{\mathrm{a}}$ \\
South & $0.017^{\mathrm{b}}$ & $0.016^{\mathrm{b}}$ & & $0.088^{\mathrm{a}}$ & $0.090^{\mathrm{a}}$ & $0.091^{\mathrm{a}}$ \\
Foreign & $0.014^{\mathrm{b}}$ & $0.036^{\mathrm{b}}$ & $0.237^{\mathrm{b}}$ & & $0.092^{\mathrm{a}}$ & $0.091^{\mathrm{a}}$ \\
Portuguese & $0.007^{\mathrm{b}}$ & $0.012^{\mathrm{b}}$ & $0.012^{\mathrm{b}}$ & $0.026^{\mathrm{b}}$ & & $<0.001^{\mathrm{a}}$ \\
C-Pt & $0.005^{\mathrm{b}}$ & $0.012^{\mathrm{b}}$ & $0.012^{\mathrm{b}}$ & $0.028^{\mathrm{b}}$ & $0.986^{\mathrm{b}}$ & \\
\hline
\end{tabular}

\footnotetext{
${ }^{\mathrm{a}}$ Biodistance results between each pair of samples

${ }^{\mathrm{b}}$ Significance of the MMD

C-Pt Coimbra (Portugal) full sample
} 
other than the northern and southern parts of the peninsula (Santos et al. 2014). This lack of difference between the north and south may be related to the relocation of former MuslimChristian converts during the reconquest, escape of cryptic Muslims to safer regions in the sixteenth century, and preIslamic contact, since the Spanish Y chromosome evidence points to the stronger presence of North African and Arabian lineages in Galicia (Regueiro et al. 2015).

These data corroborate the present discovery: there is an overall genetic continuity in the Portuguese (and Iberian) regions. The slight deviation found for the south subsample may be related to the patrilineal ( $\mathrm{Y}$ chromosome) markers, which marginally differentiate a southern region.

Crown morphology microdifferentiation (distinguishing regional phenotypic variation) was widely studied, mainly using MMD. The MMD biodistances reported above are roughly comparable to others in the literature. The mean MMD of the regional comparison averages 0.066 (excluding all MMDs involving the full sample to avoid redundancy). The MMD results in Table 6 reflect biodistances lower than, or similar to, significant MMDs of Christian-era Nubians (Irish 2005), Neolithic to Roman Egyptians (Irish 2006), North American Southwest indigenous tribes (Scott and Dahlberg 1982), early Christians from a Byzantine monastery and Near East samples (Ullinger 2002), Late Bronze-to-Early Iron Age transition southern Levantines (Ullinger et al. 2005), circum-Caribbean samples (Coppa et al. 2008), and Maharashtra Indians (Lukacs et al. 1998), which are mostly biologically homogeneous samples. The MMD results reported by Manabe et al. (2003) for a much wider and diverse region, Asia, show higher-occasionally much higherbiodistances. The low biodistances found in the present analysis underline the biological continuum found for this mostly Portuguese sample from Coimbra and of the late modern/early contemporary Portuguese population as a whole.

\section{Conclusions}

The 600 individuals selected from the Coimbra-identified cranial collection, despite some diversity in year of birth, region, and even country of birth, seem to be a representative of the coeval Portuguese population. From the four generations included, the latter three are phenotypically similar. The oldest generation has a small sample that did not allow for a definitive conclusion. A noteworthy biodistance of the older generation is, however, unlikely. The three major geographical regions in Portugal show great biological affinity. Foreigners and Portuguese individuals were also biologically very close. Once again, only the small number of foreign and southern individuals available conditioned the quantitative and statistical analyses.
This very large sample's dental (and oral) discrete trait frequencies (see Appendix 1) can be very useful in understanding the genetic effects of migration into and from the current Portuguese territory. One such example is the evaluation of the biological proximity between the Portuguese population and the population of Rio de Janeiro (Brazil), which attests to the genetic importance of the millions of Portuguese colonizers and immigrants to Brazil to that country's gene pool (Marado and Silva 2014). Future research that aims to enlighten the migratory patterns of Portuguese prehistory and history can use this reliable Coimbra reference sample in biodistance analyses.

Acknowledgements The authors wish to thank the Department of Life Sciences, Faculty of Sciences and Technology, University of Coimbra, for the access to their identified osteological collections; Professor Joel D. Irish for the help with quantitative and statistical methods and support; Professor Arkadiusz Soltysiak for the help with the R program and his MMD R script; and Professor Sofia Wasterlain for the helpful comments which inspired this work and previous statistical guidance. The first author's contribution was funded by the Fundação para a Ciência e as Tecnologias (FCT; Ministério da Educação e Ciência) with the scholarship reference SFRH/BD/70183/2010. This project received the financial support of the Project Lab2PT-Landscapes, Heritage and Territory Laboratory-AUR/04509 and FCT through the national funds and when applicable of the FEDER co-financing, in the aim of the new partnership agreement PT2020 and COMPETE2020-POCI 010145 FEDER 007528 .

Compliance with ethical standards

Conflict of interest The authors declare that they have no conflict of interest.

\section{References}

Adams SM, Bosch E, Balaresque PL, Ballereau SJ, Lee AC, Arroyo E, López-Parra AM, Aler M, Gisbert Grifo MS, Brion M, Carracedo A, Lavinha J, Martínez-Jarreta B, Quintana-Marci L, Picornell A, Ramon M, Skorecki K, Behar DM, Calafell F, Jobling MA (2008) The genetic legacy of religious diversity and intolerance: paternal lineages of Christians, Jews, and Muslims in the Iberian Peninsula. Am J Hum Genet 83:725-736

Beleza S, Gusmão L, Lopes A, Alves C, Gomes I, Giouzeli M, Calafell F, Carracedo A, Amorim A (2006) Micro-phylogeographic and demographic history of Portuguese male lineages. Ann Hum Genet 70: 181-194

Bocquet-Appel JP (1984) Biological evolution and history in 19th century Portugal. In: van Vark GN, Howells WW (eds) Multivariate statistical methods in physical anthropology. Reidel Publishing Company, Boston, pp. 289-321

Brandt G, Szécsényi-Nagy A, Roth C, Alt KW, Haak W (2014) Human paleogenetics of Europe of - the known knowns and the known unknowns. J Hum Evol 79:73-92

Burnett SE, Hawkey DE, Turner CG (2010) Brief communication: population variation in human maxillary premolar accessory ridges (MxPAR). Am J Phys Anthropol 141(2):319-324 
Burnett SE, Irish JD, Fong MR (2013) Wear's the problem? Examining the effect of dental wear on studies of crown morphology. In: Scott GR, Irish JD (eds) Anthropological perspectives on dental morphology: genetics, evolution, variation. Cambridge University Press, New York, pp. 535-554

Collins R (2004) Visigothic Spain. Blackwell, Oxford, pp. 409-711

Coppa A, Cucina A, Hoogland MLP, Lucci M, Luna Calderón F, Panhuysen RGAM, Tavarez María G, Valcárcel Rojas R, Vargiu R (2008) New evidence of two different migratory waves in the circum-Caribbean area during the pre-Columbian period from the analysis of dental morphological traits. In: Hoffman CL, Hoogland MLP, van Gijn AL (eds) Crossing the borders: new methods and techniques in the study of archaeological materials from the Caribbean. The University of Alabama Press, Tuscaloosa, pp. 195-213

Cunha E, Wasterlain S (2007) The Coimbra identified osteological collections. In: Grupe G, Peters J (eds) Skeletal series and their socioeconomic context. Verlag Marie Leidorf GmbH, Rahden/Westf, pp. 23-33

Delgado-Burbano ME (2007a) Population affinities of African Colombians to Sub-Saharan Africans based on dental morphology. Homo 58(4):329-356

Delgado-Burbano ME (2007b) Variación dental no-métrica y el tráfico de esclavos por el atlántico: la ascendencia biológica y los orígenes geográficos de una población afro-colombiana. Revista Española de Antropología Física 27:13-32

Díaz PC (2000) Sedes regiae (ann. 400-800). In: Ripoll G, Gurt JM (eds) El Reino Suevo de Hispania y su sede en Bracara. Reial Academia de Bones Lletres, Barcelona

Edgar HJH (2004) Dentitions, distance, and difficulty: a comparison of two statistical techniques for dental morphological data. Dental Anthropology 17(2):55-62

Fenner JN (2005) Cross-cultural estimation of the human generation interval for use in genetics-based population divergence studies. Am J Phys Anthropol 128(2):415-423

Freeman MF, Tukey JW (1950) Transformations related to the angular and the square root. Ann Math Stat 21:607-611

Gamito TJ (2005) The Celts in Portugal. e-Keltoi 6:571-605

Harris EF (2008) Statistical applications in dental anthropology. In: Irish JD, Nelson GC (eds) Technique and application in dental anthropology. Cambridge University Press, New York, pp. 35-67

Harris EF, Sjøvold T (2004) Calculation of Smith's mean measure of divergence for intergroup comparisons using nonmetric data. Dental Anthropology 17(3):83-93

Hauser G, De Stefano GF (1989) Epigenetic variants of the human skull. E. Schweizerbart'sche Verlagsbuchhandlung (Nagele u. Obermiller), Stuttgart

Igrejas LM (2007) O Celtismo na Galiza: Algumas controvérsias Ideologia e ciência na definição do passado Céltico Galego. Análise empresarial 38:78-79

Irish JD (1998) Dental morphological affinities of Late Pleistocene through recent sub-Saharan and North African peoples. Bull Mém Soc Anthropol Paris 10(3):237-272

Irish JD, Guatelli-Steinberg D (2003) Ancient teeth and modern human origins: an expanded comparison of African Plio-Pleistocene and recent world dental samples. J Hum Evol 45(2):113-144

Irish JD (2005) Population continuity vs. discontinuity revisited: dental affinities among Late Paleolithic through Christian-era Nubians. Am J Phys Anthropol 128:520-535

Irish JD (2006) Who were the ancient Egyptians? Dental affinities among Neolithic through postdynastic peoples. Am J Phys Anthropol 129: 529-543

Jackes M, Lubell D, Meiklejohn C (1997) Healthy but mortal: human biology and the first farmers of Western Europe. Antiquity 71:639-658
Jackes M, Silva AM, Irish J (2001) Dental morphology: a valuable contribution to our understanding of prehistory. Journal of Iberian Archaeology 3:97-119

Lorrio AJ, Ruiz Zapatero G (2005) The Celts in Iberia: an overview. eKeltoi 6:167-254

Lukacs JR, Hemphill BE, Walimbe SR (1998) Human dental development, morphology, and pathology: a tribute to Albert A. Dahlberg. In: Lukacs JR (ed) Are Mahars autochthonous inhabitants of Maharashtra?: a study of dental morphology and population history in South Asia. University of Oregon Anthropological Papers, Eugene

Mairal Q, Santos C, Silva M, Marques SL, Ramos A, Aluja MP, Amorim A, Prata MJ, Alvarez L (2013) Linguistic isolates in Portugal: insights from the mitochondrial DNA pattern. For Sci Int Genetics 7: 618-623

Manabe Y, Oyamada J, Kitgawa Y, Rokutanda A, Kato K, Matsushita T (2003) Dental morphology of the Dawenkou Neolithic population in North China: implications for the origin and distribution of Sinodonty. J Hum Evol 45:369-380

Marado LM (2014) Characterization of the dental morphology of a Portuguese sample from the 19th and 20th centuries. $\mathrm{PhD}$ thesis. Universidade de Coimbra, Coimbra

Marado LM, Silva AM (2014) Ties between Portugal and Brazil: a contribution from dental morphology. In: Bitencourt Campos J, Zocche JJ, Cerezer JF, Oosterbeek LM (eds) Arqueologia Ibero-americana e Transatlântica: Arqueologia, Sociedade e Território. Habilis press Editora, Criciúma, pp 313-326

Marado LM, Silva LM (2016) The mandibular molar pit-tubercle (MMPT) dental nonmetric trait: comprehensive analysis of a large sample. Homo. doi:10.1016/j.jchb.2016.09.003

Martiniano R, Feitosa Y, Abade A, Manco L (2013) Y-chromosome diversity in central Portugal reveals signatures of ancient maritime expansions. Anthrop Anz 70(4):355-367

McEvoy B, Richards M, Forster P, Bradley DG (2004) The longue durée of genetic ancestry: multiple genetic marker systems and Celtic origins on the Atlantic facade of Europe. Am J Hum Genet 75:693-702

Mendes Corrêa AA (1919) Origins of the Portuguese. Am J Phys Anthropol 2(2):117-145

Pereira L, Morales AC, Goios A, Duarte R, Rodrigues C, Endicott P, Alonso A, Martin P, Torres C, Amorim A (2006) The Islamization of Iberian Peninsula: a demographic shift or a cultural change? Search for an answer using extant and ancient DNA from Mértola (Southeast Portugal). Int Congr Ser 1288:828-830

Pereira L, Prata MJ, Amorim A (2000) Diversity of mtDNA lineages in Portugal: not a genetic edge of European variation. Ann Hum Genet 64:491-506

Ralph P, Coop G (2013) The geography of recent genetic ancestry across Europe. PLoS Biol 11(5):e1001555

R Core Team (2013) R: a language and environment for statistical computing. R Foundation for Statistical Computing, Vienna

Regueiro M, Garcia-Bertrand R, Fadlhaoui-Zid L, Álvarez J, Herrera RJ (2015) From Arabia to Iberia: a Y chromosome perspective. Gene 564:141-152

Rocha MA (1995) Les collections ostéologiques humaines identifiées du Musée Anthropologique de l'Université de Coimbra. Antropol Port 13:121-138

Sampietro ML, Caramelli D, Lao O, Calafell F, Comas D, Lari M, Agustí B, Bertranpetit J, Lalueza-Fox C (2005) The genetics of the preRoman Iberian Peninsula: a mtDNA study of ancient Iberians. Ann Hum Genet 69:535-548

Santos C, Fregel R, Cabrera VM, Álvarez L, Larruga JM, Ramos A, López MA, Aluja MP, González AM (2014) Mitochondrial DNA and Y-chromosome structure at the Mediterranean and Atlantic façades of the Iberian Peninsula. Am J Hum Biol 26:130-141

Scott GR, Dahlberg AA (1982) Microdifferentiation in tooth crown morphology among Indians of the American Southwest. In: Kertén B 
(ed) Teeth: form, function and evolution. Columbia University Press, New York, pp. 259-291

Scott GR, Turner CG (1997) The anthropology of modern human teeth. Dental morphology and its variation in recent human populations. Cambridge University Press, Cambridge

Silverstein AJ (2010) Islamic history. A very short introduction. Oxford University Press, New York

Sobral JM (2004) O Norte, o Sul, a raça, a nação - representações da identidade nacional portuguesa (séculos XIX-XX). Análise Social XXXIX(171):255-284

Soltysiak A (2011) An R script for Smith's mean measure of divergence. Bioarchaeology of the Near East 5:41-44

Tsirkin JB (1989) The veterans and the Romanization of Spain. Gérion 7: $137-147$

Turner CG (1985) Expression count: a method for calculating morphological dental trait frequencies by using adjustable weighting coefficients with standard ranked scales. Am J Phys Anthropol 68:263-267

Turner CG, Nichol CR, Scott GR (1991) Scoring procedures for key morphological traits of the permanent dentition: the Arizona State University dental anthropology system. In: Kelley MA, Larsen CS (eds) Advances in dental anthropology. Wiley-Liss, New York, pp. $13-31$
Tyrrell A (2000) Skeletal non-metric traits and the assessment of interand intra- population diversity: past problems and future potential. In: Cox M, Mays S (eds) Human osteology in archaeology and forensic science. Greenwich Medical Media, London, pp. 289-306

Ullinger JM (2002) Early Christian pilgrimage to a Byzantine Monastery in Jerusalem - a dental perspective. Dental Anthropology 16(1):22-25

Ullinger JM, Sheridan SG, Hawkey DE, Turner CG, Cooley R (2005) Bioarchaeological analysis of cultural transition in the Southern Levant using dental nonmetric traits. Am J Phys Anthropol 128: 466-476

Weets JD (2004) A dental anthropological approach to issues of migration and population continuity in ancient Ireland $[\mathrm{PhD}]$. Pennsylvania State University

Weets JD (2009) A promising mandibular molar trait in ancient populations of Ireland. Dental Anthropology 22(3):65-72

Weisensee KE, Jantz RL (2011) Secular changes in craniofacial morphology of the Portuguese using geometric morphometrics. Am J Phys Anthropol 145:548-559

Zilhão J (1993) The spread of agro-pastoral economies across Mediterranean Europe: a view from the far west. J Mediterr Archaeol 6(1):5-63 